\title{
Evaluation of Factors Affecting Patient Satisfaction with Health Care Services: A Cross-sectional Study in an Endourology Clinic
}

\author{
Sağlık Hizmeti Verilirken Hasta Memnuniyetine Etki Eden Faktörlerin Değerlendirilmesi: \\ Endoüroloji Kliniğinde Kesitsel Bir Çalışma
}

\author{
(D) Reha Girgin, (D) Engin Denizhan Demirkıran, (D) Günnur Yılmaz \\ Zonguldak Bülent Ecevit University Faculty of Medicine, Department of Urology, Zonguldak, Turkiye
}

\section{What's known on the subject? and What does the study add?}

It is known that the patients who receive inpatient treatment and their relatives are in expectation from the hotel and health personnel services rather than the treatment method. Although some regulations are still needed in our country, it seems that there is no need to allocate high budgets.

\begin{abstract}
Objective: Quality in health care services means delivering health services using medical technologies by taking into account patients' expectations. Patient satisfaction is the response to this service. The quality of health care provided is an important determinant of health service utilization and the choice of health facility. The aim of this study was to evaluate the satisfaction levels and expectations of health care services provided to patients who underwent endourological treatment.

Materials and Methods: Patients who underwent endourological treatment in our clinic between February 2018 and April 2018 and/or their accompanists were asked to complete a questionnaire consisting of 20 questions before discharge. Demographic characteristics of the participants and their opinion on the services provided and the staff providing the services were analyzed using the independent samples t-test, one-way analysis of variance, and Tukey's post-hoc test.

Results: A total of 150 individuals participated in the study. $94 \%$ of the participants were patients' accompanists. Of the participants, $48.7 \%$ were women, 52.7\% were 35-60 years olds, 62\% were high school graduates, 24\% were workers and 5.3\% were civil servants.

There was no statistically significant difference between the satisfaction levels of the participants according to their gender, age, education level, occupational status, proximity to the patient and length of hospital stay.

Conclusion: In our study, it was seen that perception of quality of health services was not affected by socio-cultural and socio-economic conditions of patients and their accompanists.

Keywords: Patient satisfaction, Quality in health, Endourology

Öz

Amaç: Sağlık hizmetinde kalite, sağlık sunum sürecinin tıp teknolojilerinin hasta beklentileri de göz önünde tutularak verilmesini ifade etmektedir. Hasta memnuniyeti verilen bu hizmete gösterilen tepkidir. Verilen sağlık hizmetinin kalitesi hasta ve yakınlarının aynı üniteyi tekrar tercih etmede, önemli bir etkendir. Bu çalışmada endoürolojik tedavi almış hastalara sunulan sağlık hizmetlerinden memnuniyet düzeylerini ve beklentilerini değerlendirmek amacıyla yapılmıştır.

Gereç ve Yöntem: Şubat 2018 ve Nisan 2018 tarihleri arasında kliniğimizde endoürolojik tedavi görmüş hasta ve/veya yakınlarından taburculuk öncesi önceden hazırlanmış 20 adet sorudan oluşan anket formunu doldurmaları istendi. Bağımsız t-testi, tek yönlü varyans analizi, post hoc Tukey testlerinden yararlanılarak katılımcıların demografik özellikleri ile servis ve personel hizmeti ile ilgili düşünceleri hakkındaki görüşleri analiz edildi.
\end{abstract}

Correspondence: Reha Girgin MD, Zonguldak Bülent Ecevit University Faculty of Medicine, Department of Urology, Zonguldak, Turkiye E-mail: mujdereha@hotmail.com ORCID-ID: orcid.org/0000-0003-1132-8629

Received: 28.02.2019 Accepted: 11.09.2019

Cite this article as: Girgin R, Demirkıran ED, Yılmaz G. Evaluation of Factors Affecting Patient Satisfaction with Health Care Services: A Cross-sectional Study in an Endourology Clinic. J Urol Surg 2019;6(4):278-282.

๑Copyright 2019 by the Association of Urological Surgery / Journal of Urological Surgery published by Galenos Publishing House. 
Bulgular: Çalışmaya 150 hasta ve yakını katılmıştır. Katılımcıların \%94'ünü hasta refakatçileri oluşturmuştur. Katılımcıların \% 48,7'ünün kadın, \%52,7'sinin 35-60 yaşları arasında, \%62'sinin lise mezunu, \%24'ünün işçi, \%5,3'ünün memur olduğu bulunmuştur. Katılımcıların cinsiyetlerine, yaş dağılımlarına, öğrenim düzeylerine, mesleki durum, hastayla yakınlık dereceleri ve servisteki yatış sürelerine göre memnuniyet anketi puan ortalamalarına bakıldığında istatistiksel olarak anlamlı farklılık olmadığı görülmüştür.

Sonuç: Çalışmamız da sağlık hizmetinde kalite algısının hastaların ve yakınlarının sosyo-kültürel ve sosyo-ekonomik koşullarından etkilenmediği görülmüştür.

Anahtar Kelimeler: Hasta memnuniyeti, Sağlıkta kalite, Endoüroloji

\section{Introduction}

Quality is defined as the degree of excellence (1), and health care quality refers to the provision of health services by considering patient expectations in the light of the last point reached in technology and medicine (2). Patient satisfaction is accepted as the most objective indicator of the service quality and service outcome in a health facility. Patient satisfaction is defined as the basic criterion that gives information about the level of patient's values and expectations and shows the quality of patient care. In patient satisfaction research, many dimensions such as satisfaction with health care staff's communication skills, trust in staff, patient privacy, honesty of the staff, courtesy, providing adequate information, hospital cleanliness and hotel services are discussed $(3,4)$. The quality of health care provided is an important determinant of health service utilization and the choice of health facility. In recent years, the changes in the health system in our country have enabled patients select hospital and physician regardless of their health insurance. This study was carried out in order to evaluate the satisfaction levels and expectations of patients in the endourology clinic who were admitted to the endourology clinic in Zonguldak Bülent Ecevit University Hospital under the current conditions. The main aim of the study was to learn how the quality of medical and nursing services perceived by the patients and determine the factors affecting satisfaction.

\section{Materials and Methods}

After approval of the local ethics committee (ethics committee protocol no. 2018-19-17/01) and after obtaining consent from patients, who received endourological treatment between February and April 2018 in Zonguldak Bülent Ecevit University Medical Faculty Department of Urology, and/or their accompanists were asked to fill out a questionnaire consisting of 20 questions about inpatient ward conditions and quality of service provided by the staff (Table 1). With this questionnaire, age of the participants, length of hospital stay, reason for hospitalization, level of education, the degree of proximity of the accompanist to the patient, occupational status, and opinion on the unit and the staff providing service were recorded. SPSS 23.0 program was used in the analysis of the data and independent samples t-test, one-way analysis of variance and Tukey's post-hoc test were used for statistical analysis.

\section{Results}

The sociodemographic characteristics of the patients are presented in Table 2. A total of 452 patients received endourological treatment. 150 patients who were able to participate in the survey without any external support and/or their accompanists were included in the study. 94\% of the participants were patient accompanist. Of the participants, $48.7 \%$ were women, $52.7 \%$ aged $35-60$ years, $62 \%$ - high school graduates, $24 \%$ - workers and 5.3\% - civil servants. The distribution of the responses of the participants to the questionnaire is presented in Table 3. Attention to the needs of the patients given by the doctor and the nurses received the maximum patient satisfaction ratings. The participants reported a moderate level of satisfaction with being able to take part in patient care, asking questions and participating in the information sharing and decision making

Table 1. Improved family satisfaction questionnaire for inpatient units

Only one of the family members and the person who came the most should fill in this questionnaire. Answer the survey as honestly as possible. When your patient is in the ward, take the option that best reflects your satisfaction with your care. After completing the questionnaire, hand over the form to the nurses or doctors.

Age

\begin{tabular}{|l|l|l|l} 
a) $18-24$ & b) $25-34$ & c) $35-60$ & d) Over 60
\end{tabular}

Number of days in unit

\begin{tabular}{|l|l|l|l}
\hline a) 0-3 & b) 3-7 & c) 7-10 & d) over 10
\end{tabular}

Proximity to the patient

\begin{tabular}{|c|c|c|c|}
\hline a) Husband & b) Wife & c) Mother & d) Father \\
\hline e) Son & f) Daughter & g) Sibling & h) Cousin \\
\hline i) Uncle & j) Aunt & k) Friend & I) Partner \\
\hline \multicolumn{4}{|l|}{ m) Other } \\
\hline \multicolumn{4}{|l|}{ Education } \\
\hline a) Primary school & $\begin{array}{l}\text { b) Secondary } \\
\text { school }\end{array}$ & c) High school & d) University \\
\hline \multicolumn{4}{|l|}{ Profession } \\
\hline a) Housewife & b) Retired & c) Worker & d) Officer \\
\hline e) Student & f) Not working & & \\
\hline
\end{tabular}


for examinations, treatment and recovery, quality of care given to the patient, frequency of visits and promptness of staff in responding patients' request of assistance. The vast majority of respondents expressed low level of satisfaction with wait time for examination results, appearance and cleanliness of the waiting room, comfort of the waiting lounge, patient motivation and the level of surrounding sounds within the ward. Table 2 shows the relationship of satisfaction questionnaire mean scores with sociodemographic characteristics. There was no statistically significant relationship of average satisfaction score with gender, age, level of education, occupational status, degree of proximity the accompanist to the patient, and length of stay in the ward.

\section{Discussion}

Inpatients and their accompanists have expectations when receiving service from the health facility. With evaluation of these expectations, health service providers may improve their service quality. There are many studies in the literature on this subject.

Satisfaction is a balance between patient expectations and perception of quality of service provided and we can predict that many factors can affect patient satisfaction. In our study, we could not find any significant association between satisfaction level and gender of the participants as in studies by Kıdak and Aksaraylı (5), Tezcan et al. (6) and Savaş and Bahar (7). In a study by Yıldız and Yıldız (8), it was found that older people were more satisfied than young people. In a study by Türkuğur et al. it was seen that satisfaction was higher in those born before 1971 (9). However, when we look at the age distribution of the participants, it was observed that most of them were at an age that they witnessed the changes in the healthcare system in the country. We think that this fact affected the perception of satisfaction.

In their study, Türkuğur et al. (9) reported that satisfaction increased as the level of education increased. In a study by Icçli et al. (10), a similar conclusion was reached. In their study, Sarp and Tükel (11) reported a positive correlation between dissatisfaction with hospital services and increased educational level. In a study conducted on 275 patients in Sweden, no correlation was observed between patient satisfaction and age or gender, however, it was reported that individuals with a higher educational level had a different view of the care given compared those with lower educational background (12). In our study, there was no correlation between educational level and satisfaction level. The fact that our hospital is the only research

\begin{tabular}{|c|c|c|c|c|c|}
\hline \multicolumn{6}{|c|}{ Please rate the following questions (1 showing the lowest and showing the highest satisfaction) } \\
\hline 1. Honesty of the staff about the patient's condition & 1 & 2 & 3 & 4 & 5 \\
\hline 2. The ability to talk to doctors regularly & 1 & 2 & 3 & 4 & 5 \\
\hline 3. Waiting time for examination results & 1 & 2 & 3 & 4 & 5 \\
\hline 4. Nursing services & 1 & 2 & 3 & 4 & 5 \\
\hline 5. To be able to take part in patient care & 1 & 2 & 3 & 4 & 5 \\
\hline 6. Sufficient explanation of examinations and treatments & 1 & 2 & 3 & 4 & 5 \\
\hline 7. Promptness of the staff in responding patient's request of assistance & 1 & 2 & 3 & 4 & 5 \\
\hline 8. The appearance and cleanliness of the waiting lounge & 1 & 2 & 3 & 4 & 5 \\
\hline 9. Comfort of the waiting lounge & 1 & 2 & 3 & 4 & 5 \\
\hline 10. Encouragement when my patient was in the ward & 1 & 2 & 3 & 4 & 5 \\
\hline 11. Sufficient answers to our questions & 1 & 2 & 3 & 4 & 5 \\
\hline 12. The quality of care given to my patient & 1 & 2 & 3 & 4 & 5 \\
\hline 13. Sharing the decisions about my patient with me & 1 & 2 & 3 & 4 & 5 \\
\hline 14. To be able to meet regularly with the nurse & 1 & 2 & 3 & 4 & 5 \\
\hline 15. Attention of the doctor and the nurses to the needs of the patient & 1 & 2 & 3 & 4 & 5 \\
\hline 16. Respect for patient privacy during visits & 1 & 2 & 3 & 4 & 5 \\
\hline 17. Preoperative preparation of the patient for surgey & 1 & 2 & 3 & 4 & 5 \\
\hline 18. Frequency of visit hours & 1 & 2 & 3 & 4 & 5 \\
\hline 19. The level of surrounding sounds within the ward & 1 & 2 & 3 & 4 & 5 \\
\hline 20. To be included in the discussions about the recovery of my patient & 1 & 2 & 3 & 4 & 5 \\
\hline
\end{tabular}


center in the region and the number of external patients is low affects our data.

In our study, we did not see any correlation between satisfaction level and occupational status, unlike previously reported by Türkuğur and his colleagues. We think this may be caused by the fact that although there was a difference in professional status, the economical status was similar between the participants. Additionaly, we did not see any correlation of satisfaction level with the degree of proximity of the patient accompanist to the patient and length of hospital stay.

Kıdak and Aksaraylı (5) found that patient satisfaction with the physicians was more important in the general evaluations, and hence, it was emphasized that physicians were more effective in patients' hospital preferences. In our opinion, doctors should be in good communication with patients. In this study, attitudes and behaviors of physicians were found to have an important effect on overall satisfaction of patients. Patients are in contact with nurses rather than doctors. For this reason, nurses' experience and behavior are very important in terms of patient satisfaction. In general, patients' satisfaction with nursing services was found to be high.
It is seen that long time spent waiting for examinations, discomfort in the waiting room and high level of surrounding sounds within the hospital environment were the most disturbing situations for patients and their accompanists.

The fact that the number of patient accompanists included in the study was higher than patients may be a limitation of our study. In addition, the fact that our hospital is a peripheral hospital reduces the likelihood of visits from different regions and different ideas It should also be kept in mind that this study performed in an endourology clinic may not reflect the views of patients undergoing open surgery. We believe that more objective results can be obtained in centers with larger and diverse patient populations.

\section{Conclusion}

In our study, it was observed that perception of quality of health care was not affected by socio-cultural and socio-economic conditions of patients and their accompanists. It is known that patients who are receiving inpatient treatment and their accompanists are in the expectation of a good hotel and health personnel service rather than the treatment method Although

Table 3. The distribution of the responses of the participants to the questionnaire

\begin{tabular}{|c|c|c|c|}
\hline & High* $^{*}(\%)$ & Moderat* n (\%) & Low $^{*}$ n (\%) \\
\hline 1. Service employees' honesty about the patient's condition & $142(94.6 \%)$ & $6(4.0 \%)$ & $2(1.3 \%)$ \\
\hline 2. The ability to talk to doctors regularly & $138(92.0 \%)$ & $4(2.6 \%)$ & $8(25.3 \%)$ \\
\hline 3. Waiting time for examination results & $125(83.3 \%)$ & $12(8.0 \%)$ & $13(8.6 \%)$ \\
\hline 4. Nursing services & $142(94.6 \%)$ & $7(4.6 \%)$ & $1(0.6 \%)$ \\
\hline 7. The quickness of employees in emergency and assistance requests & $137(91.3 \%)$ & $6(4.0 \%)$ & $7(4.6 \%)$ \\
\hline 8. The appearance and cleanliness of the waiting lounge & $122(81.3 \%)$ & $14(9.3 \%)$ & $14(9.3 \%)$ \\
\hline 9. Comfort of the waiting lounge & $113(75.3 \%)$ & $22(14.6 \%)$ & $15(10.0 \%)$ \\
\hline 10. Encouragement when my patient was in the ward & $127(84.6 \%)$ & $15(10.0 \%)$ & $8(25.3 \%)$ \\
\hline 13. Sharing the decisions about my patient with me & $138(92.0 \%)$ & $5(3.3 \%)$ & $7(4.6 \%)$ \\
\hline 14. To be able to meet regularly with the nurse & $142(94.6 \%)$ & $5(3.3 \%)$ & $7(4.6 \%)$ \\
\hline 15. From the attention of the doctor and the nurses to the needs of the patient & $143(95.3 \%)$ & $3(2.0 \%)$ & $4(2.6 \%)$ \\
\hline 16. Sensitivity about patient privacy during visits & $142(94.6 \%)$ & $5(3.3 \%)$ & $3(2.0 \%)$ \\
\hline 17. Preparations made during the patient's departure to operation & $143(95.3 \%)$ & $3(2.0 \%)$ & $4(2.6 \%)$ \\
\hline 18. Frequency of visit hours & $141(94.0 \%)$ & $5(3.3 \%)$ & $4(2.6 \%)$ \\
\hline 19. The volume at the service & $113(75.3 \%)$ & $17(11.3 \%)$ & $20(13.3 \%)$ \\
\hline 20. To be included in the discussions about the recovery of my patient & $138(92.0 \%)$ & $8(25.3 \%)$ & $4(2.6 \%)$ \\
\hline
\end{tabular}


certain regulations are still needed in our country, it is seen that there is no need to allocate high budgets.

\section{Ethics}

Ethics Committee Approval: Approval of the local ethics committee (protocol no: 2018-19-17/01).

Informed Consent: Consent form was filled out by all participants.

Peer-review: Externally peer-reviewed.

\section{Authorship Contributions}

Concept: R.G., Design: R.G., Data Collection or Processing: E.D.D., G.Y., Analysis or Interpretation: R.G., E.D.D., Literature Search: R.G., E.D.D., Writing: R.G.

Conflict of Interest: No conflict of interest was declared by the authors.

Financial Disclosure: The authors declare that they have no relevant financial.

\section{References}

1. Özgen H. Sağlık bakım hizmetlerinde kalite nedir? Hasta tatmin boyutuyla ilgili bir değerlendirme. Toplum ve Hekim Dergisi 1995;10:47-53.

2. Uz H. Temel sağlık hizmetlerinde kalitenin sürekli iyileştirilmesi için gereken ön koşullar ve bu konuda Danimarka tecrübeleri. I. Basamak Sağlık
Hizmetlerinde TKY Sempozyumu, Haberal Eğitim Vakfı Yayınları, Ankara, 1995.

3. Ayaz H, Soykan A. Toplam kalite yönetimi ve sağlık sektörü. T Klin Psikiyatri 2002;3:19-26.

4. Kırılmaz H. Hasta memnuniyetini etkileyen faktörlerin sağlık hizmetlerinde performans yönetimi çerçevesinde incelenmesi: poliklinik hastaları üzerine bir araştırma. ACU Sağlık Bil Derg 2013:11-21.

5. Kıdak L, Aksaraylı M. Yatan hasta memnuniyetlerinin değerlendirilmesi ve izlenmesi: eğitim ve araştırma hastanesi uygulaması. DEU Journal of GSSS 2008;10:87-122.

6. Tezcan D, Yücel HM, Ünal UB, Edirne T. Üçüncü basamak sağlık kuruluşunda hasta memnuniyeti. Pamukkale Medical Journal 2013;7:57-62.

7. Savaş $E_{1}$ Bahar A. Gaziantep üniversitesi tıp fakültesi hastanesinde yatan hastaların memnuniyet düzeylerinin belirlenmesi. Gaziantep Medical Journal 2011;17:24-28.

8. Yıldız S, Yıldız SE. Hizmet kalitesinin müşteri memnuniyetine etkisi: Kars'taki devlet ve üniversite hastanelerinde bir araştırma. JKEM 2011;6:125-140.

9. Türkuğur Ü, Alıcı B, Uzuntarla $Y$, Güleç M. Yatan hasta memnuniyetinin incelenmesi: Bir eğitim hastanesi örneği. Gulhane Med J 2016;58:170-173.

10. İçli GE, Kuğuoğlu $\mathrm{S}$, Aslan FE. Sosyodemografik değişkenlerin hasta memnuniyetine etkisi. Marmara Üniversitesi IïBF Dergisi 2006;21:383-400.

11. Sarp N, Tükel B. İbn-i Sina Hastanesinde hasta memnuniyeti araştırması. ANKARA ÜNIVERSITESI TIP FAKÜLTESI MECMUASI 1999;52:147-151.

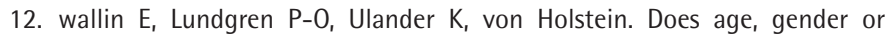
educational background effect patient satisfaction with short stay surgery? Ambulatory Surgery 2000;8:79-88. 